\title{
CORRIGENDUM
}

\section{Process and outcome in communication of genetic information within families: a systematic review}

\author{
Clara L Gaff, Angus J Clarke and Paul Atkinson
}

European Journal of Human Genetics (2008) 16, 402; doi:10.1038/sj.ejhg.5201971

European Journal of Human Genetics (2007) 15, 999-1011. doi:10.1038/sj.ejhg.5201883

Correction to: European Journal of Human Genetics (2007) 15, 999-1011. doi:10.1038/sj.ejhg.5201883; published online 4 July 2007
An amended Table 1 is available online as the original formatting meant that some study information and findings were not clearly linked to the appropriate manuscript. 